\title{
The comparison of the Butzler medium, filtration technique and their association with isolation of Campylobacter ssp
}

\author{
Comparação do meio de Butzler, técnica de filtração e sua \\ associação para o isolamento de Campylobacter ssp
}

José Rafael Modolo

\begin{abstract}
Campylobacter was isolated in 178 out of 622 stool samples (200 porcine, 220 bovine, and 202 canine). From these 178 samples, the microorganism was identified in 64 samples (36\%) isolated only in Butzler selective medium (BSM), 34 samples (19\%) using filtration technique (FT), and in 80 samples (45\%) using both BSM and FT. Comparison of the proportion of positivity using both techniques showed a significant value $\left.\chi^{2}=9,184 ; p>0.001\right)$; BSM (36\%) being more efficient than $F T(19 \%)$. The use of both techniques yielded the highest isolation positivity (45\%). Key-words: Campylobacter. Butzler medium. Filtration technique. Comparison.
\end{abstract}

Resumo Do total de 622 amostras de fezes, sendo 200 de suínos, 220 de bezerros e 202 de cães, Campylobacter foi isolado em 178 amostras. Destas, o agente foi identificado em 64 (36\%) amostras, isoladas somente em meio seletivo de Butzler (MSB); em 34 (19\%) o microorganismo foi isolado a partir da técnica de filtração (TF) e em 80 (45\%), através de ambos os procedimentos (MSB+TF). A comparação entre as proporções de positividade, pelas diferentes técnicas, revelou significância $\left(\chi^{2}=9.184 ; p>0,001\right)$ sendo a MSB $(36 \%)$ a mais eficiente comparada com a TF (19\%) O uso associado de ambos os procedimentos proporcionou a positividade mais elevada de isolamento com $45 \%$.

Palavras-chaves: Campylobacter. Meio de Butzler. Técnica de filtração. Comparação.

From the 1970's on, it was possible to evaluate the importance of enteric campybolobacteriosis, a disease affecting animals and humans, to better correlate Campylobacter with enteropathies, as well as to conduct further epidemiological studies, mainly those related to zoonoses. This was made possible due to the introduction of new selective culture mediums and filtration techniques. These made possible the elimination undesirable microorganisms from the analysis samples.

The presence of different antimicrobials, added to these media as microbian decontaminants, may exert a selective pressure in Campylobacter growth, making its isolation more difficult ${ }^{5}$.
Bolton et al. ${ }^{2}$ observed microorganisms resistant to the antimicrobials present in the selective medium. These authors also observed that the filtration technique was very effective for decontamination.

However, the presence of substances, cell debris, and microorganisms in the supernatant may cause the closing of the filter membrane pores, even after centrifuging ${ }^{13}$.

Thus, the objective of this study is to compare the Butzler selective medium (BSM) and the filtration technique (FT) for the isolation of Campylobacter from feces samples ${ }^{34}$.

Faculdade de Medicina Veterinária e Zootecnia da Universidade Estadual Paulista (UNESP), Botucatu, SP. Endereço para correspondência: Dr. José Rafael Modolo. Caixa Postal 524, 18618-000 Botucatu, SP, Brasil. Fax: 5514 6802-6075

e-mail: j.r.modolo@fmvz.unesp.br

Recebido para publicação em 20/4/99. 
A loop of feces was streaked on Petri plates containing agar thioglycolate with $20 \%$ blood and BSM. One gram was homogenized in $9 \mathrm{ml}$ of PBS and centrifuged at $2,000 \mathrm{rpm} / 5 \mathrm{~min}$. The supernatant was filtered using a $0.65 \mu \mathrm{M} \angle$ membrane and streaked on plates with the same base, but with no selective supplement (FT). BSM plates were incubated ant $43^{\circ} \mathrm{C}$ and $\mathrm{FT}$ plates at $37^{\circ} \mathrm{C}$ for $72 \mathrm{~h}$ in microaerophilic atmosphere.

Campylobacter was isolated in 178 of the 622 feces samples (200 pig, 220 calf, and 202 dog $)^{789}$. From these 178 samples, the microorganism was identified in $64(36 \%)$ samples isolated only in
BSM, $34(19 \%)$ samples using only $\mathrm{FT}$, and in $80(45 \%)$ samples using both BSM and FT. Comparison of proportion of positivity using both techniques showed a significant value $\left(\chi^{2}=9.184\right.$; $p>0.001)$; BSM (36\%) being more effective than FT $(19 \%)$. The associated use of both techniques yielded the highest isolation positivity $(45 \%)$. We have observed that despite BSM statistical significance, the association of both techniques increases the possibility of Campylobacter isolation. This procedure would be useful in view of the different clinical and epidemiological features of campylobacteriosis.

\section{REFERÊNCIAS BIBLIOGRÁFICAS}

1. Bisping W, Kirpal G, Sonnenschein B. Diagnose und Bekãmpfung der Campylobacter fetus subsp. fetusInfektion beim Besamungsbullen. Tierärztliche Umschau 36: 667-674, 1981.

2. Bolton FJ, Hutchinson DN, Parker G. Isolations of Campylobacter. What are we missing? Jornal of Clinical Pathology 40:702-703, 1987.

3. Butzler JP, Skirrow MB. Campylobacter enteritis. Clinics in Gastroenterology 8:737-765, 1979

4. Dekeiser P, Gossuin-Detrain M, Butzler J, Sternon J. Acute enteritis due to related vibrio: first positive stool cultures. Journal of Infectious Diseases 125:390-392, 1972.

5. Fricker CR, Park RWA. Competitive ELISA, Co-agglutination and passive haemagglutination for the detection and serotyping of Campylobacter In: Grange JM (ed) Immunological techniques in microbiology. London, 1987.
6. Fricker CR, Park RW. A two-year study of the distribuition of "thermophilic" Campylobacters in human, en vironmental and food samples from the Reading area with particular reference to toxin production and heat-stable serotype. Jornal of Applied Bacteriology 66:477-490, 1989.

7. Modolo JR, Bisping W, Kirpal G. Isolamento de Campylobacter $s p$ de bezerros com e sem diarréia. Pesquisa Veterinária Brasileira 7:23-25, 1987.

8. Modolo JR, Gottschalk AF, Moreno G, Lopes CAM, Margatho LFF, Del Fava, C. Campylobacter em cães com e sem diarréia: incidência e suscetibilidade a 21 antimicrobianos. Revista de Microbiologia 22:288-292, 1991.

9. Modolo JR, Margato LFF, Gottschalk AF, Lopes CAM. Incidence of Campylobacter in swine with and without diarrhea. Revista de Microbiologia 30:9-11, 1999. 